\title{
Carbon Sequestration in Africa: The Land Tenure Problem
}

\author{
Jon D. Unruh \\ McGill University
}

\begin{abstract}
The prospect of using tropical forest projects to sequester significant amounts of atmospheric carbon as one mitigation approach to climate change has received considerable attention. In the Kyoto Protocol, the Clean Development Mechanism (CDM) aspires to make such projects viable. This article examines the prospect of these projects in Africa, and argues that land tenure is much more than just a set of variables to be changed, and that instead it exists as a prohibitive obstacle to the implementation of afforestation and reforestation sequestration approaches. Five primary tenure problems are examined: 1) the disconnect between customary and statutory land rights, 2) legal pluralism, 3) tree planting as land claim, 4) expansion of treed areas in smallholder land use systems, and 5) the difficulty of using the 'abandoned land' category. The pervasiveness of these tenurial issues mean that the prospects for successfully implementing afforestation and reforestation projects in Africa are in reality quite weak. The current project approach to carbon storage in Africa needs to be significantly realigned with African reality in order for sequestration expectations to be practical.
\end{abstract}

\section{Introduction}

As a climate change mitigation strategy the possibility of sequestering significantly large quantities of atmospheric carbon through woody biomass increment via tree planting projects in the tropics has undergone significant biophysical analysis. And indeed the spatial, and ecological potential is impressive (e.g., Houghton and Hackler, 2001; Brown, et al., 2001; Silver, et al., 2000; Sayer, et al., 2001; Achard, et al., 2002; The Royal Society, 2001). One aspect of the Kyoto Protocol considers individual afforestation and reforestation $(\mathrm{A} / \mathrm{R})$ projects within countries as a way to expand biomass sinks on a global scale, and contribute to overall carbon targets. The arrangement allows for industries in donor countries to move ahead with and take credit for specific tree planting projects in non-industrialized countries that, presumably, have the available land area to take on carbon forests (Richard and Anderson, 2001).

While Africa has contributed the least to climate change and yet will likely experience the most severe impacts (Toulmin, et al., 2005; Black, 2006), the continent has a great expanse of biophysically suitable land which could be used for placing carbon on landscapes via A/R projects (Batjes, 2001; Lal, 2002; Ringius, 2002). And, Makundi 
(1998, p. 3) notes that because sub-Saharan Africa's energy demand is 75 percent comprised of biomass, "[t]he biomass sector provides the most important near-term opportunities for reducing greenhouse gas (GHG) emissions and sequestering carbon in Africa." But while the biophysical and spatial potential for carbon sequestration in Africa is high, the socio-political potential is not, constituting a serious dilemma for carbon storage on the continent - and a similar dilemma for biofuel projects. The primary problem within this dilemma is land tenure, and no clear way ahead exists, despite the well intentioned recommendations in the $\mathrm{A} / \mathrm{R}$ carbon sequestration literature for the development and implementation of Western notions of property rights, along with improved governance, local participation, and sustainable development (Kauppi and Sedjo, 2001; Antle and Diagana, 2003; Brown, 2002; Niles, et al., 2002; Smith, 2002).

Land tenure will be the first and most fundamental issue regarding how trees are to interact with African landscapes. As a rural endeavor, the implementation of carbon forest projects in Africa would encounter a land tenure context that will almost always be much more complicated than simply state ownership or claim, or state and community approval with 'community development' benefits. The carbon sequestration literature that does include land tenure (even beyond Africa) is usually brief, general, oblique, unclear, or mistaken (e.g. Perez, et al., 2007; Braatz, et al., 2004; Smith, 2002; Trexler and Haugen, 1995). An examination of the 'on the ground' land tenure prospects of carbon sequestration in Africa has not yet been described in the literature. Yet the priority for greater understanding is explicit. "Land tenure and land law may prove to be the strongest hindrance in implementing the [sequestration] mitigation options, especially in this region where land and politics are so intertwined" (Makundi, 1998, p. 10). As for the prospects for the Clean Development Mechanism $^{1}(\mathrm{CDM})$ in Africa, of the 1,090 projects of all kinds (not only A/R) in emerging countries, only 25 are from Africa and 11 of these are in South Africa (Van der Merwe 2008). This is despite the biophysical potential, the need for sustainable development, the enormity of what are thought of as degraded areas, and the dependency on woody biomass (Desanker, 2006; Meena, 2006).

This article discusses the primary land tenure problems with attempting carbon sequestration via tree planting projects in Africa, and argues that the prospects are

\footnotetext{
${ }^{1}$ In particular the Clean Development Mechanism (CDM) in Article 12 of the Kyoto Protocol allows developed countries to meet carbon reduction objectives by specific $\mathrm{A} / \mathrm{R}$ activities in developing countries (MOE/GEC 2005). The idea behind the CDM is to assist developing countries in achieving sustainable development while participating with developed countries to achieve the latter's compliance with reduction and emission limitation commitments. The arrangement is an emissions offset trading between developing and developed countries (Yamagata and Alexandrov 2001; Toman, 2000; Brown, et al., 2001).
} 
quite dim. While widespread woody biomass increment associated with land uses does occur on the continent, it does not take place in the predicable, measureable form needed by carbon storage project efforts. The expectations for A/R carbon sequestration in Africa need to be significantly reworked, and brought more in-line with ongoing realities; which will not change to the degree needed within the time frame when large-scale carbon sequestration will have a viable impact — which is thought to be in the next few decades (Malhi et al 2002).

\section{Tenurial Constraints to carbon sequestration projects in Africa}

While the complications regarding land tenure and carbon related A/R projects are varied, in aggregate there are five features of African tenure systems that are most problematic, 1) the pervasive disconnect between customary and statutory land rights, 2) legal pluralism, 3) tree planting as land claim, 4) the functioning of treed area expansion in smallholder land use systems, and 5) the abandoned land problem. This article describes how these features operate, and how they create obstacles to A/R carbon storage on African landscapes.

\subsection{The Land Tenure Disconnect}

As the most fundamental rural property rights problem in Africa, the large social, legal, economic and often cultural disconnect between statutory land tenure, and customary or informal land tenure systems has compromised development, agriculture, nation building, and governance for decades — with a primary problem being non-recognition of customary systems by formal laws (e.g., Bruce and MigotAdholla, 1994; McAuslan, 2003; Okoth-Ogendo, 2000; Platteau, 1996; de Soto, 2000; Berry, 1997; Demsetz 1967). Most African populations conduct their lives with the idea that 'ownership' of land and trees is based on occupancy, use, lineage, and other inborn rights. However African governments often ignore customary tenure systems and regard such areas as part of the public domain, while at the same time lacking the capacity to enforce such a claim or resolve the problems that such a claim produces (Evers et al,. 2005; Moyo and Yeros 2005; Bruce and Noronha, 1987; Bruce and Fortmann, 1989). While African states can have laws and policies for the servicing of statutory efforts in land tenure, a range of problems including enforcement, politics, identity, ethnicity, financing, corruption, and the potential for conflict, preclude the effective establishment of the state's approach to land tenure over the entire national area or even most rural land in the majority of African nations (Bruce and MigotAdholla, 1994; Berry 1990; Quan 2000). Deriving functioning legal and financial institutions and increasing tenure security for small-scale producers is what international development has been attempting for decades, and the lesson is that the challenges to achieving these are immense (e.g., Creedy and Wurzbacjer, 2001; Saunders, et al., 2002; Peluso, 1992). 
While there are sound arguments for bringing small scale African landholders into a formal, uniform, national, enforceable, property rights legal code (de Soto, 2000), including regarding carbon forests (e.g. Saunders, et al., 2002); these are largely unconnected to the realities on the ground. Assertions such as "[i]f indigenous people have access to the potential freedom created by appropriate entitlements to property, they can participate in the generation of wealth that capitalism brings about" (Saunders, 2002, p. 1769) do not reflect most of African reality. More relevant to the A/R context is Antle and Diagana's (2003, p. 1182) finding that "significant issues would arise where land and property rights are not formalized. It is not clear how $[\mathrm{A} / \mathrm{R}]$ contracts would work if farmers did not hold legal title to the land they 'manage'،.

Yet formalizing land rights on the continent has been a long-term problem. Formal law in Africa can have very little to do with what most people are actually doing 'on the ground' (e.g. de Soto, 2000). And there can be little opportunity or willingness on the part of the state to formalize customs and norms that reflect ongoing informal rights and obligations about land (Unruh, 2006). Given the pervasiveness of customary law, and that attempting to replace customary law with formal law has already been tried and does not legislate human behavior into or out of existence (Bruce and Migot-Adholla, 1994; Griffiths, 1986; Moore, 1973), the problem is more complex than passing legislation, declaring land to be property of the state, seeking community participation, or providing people with title and assuming that individualized tenure and land markets will follow. This is especially true in a good number of African countries where the state will be perceived of as weak, having separate interests than those of most of the population, and of questionable legitimacy. Yet A/R projects (for a variety of purposes) in most of Africa have usually been implemented by governments, or donors acting through governments (Desanker, 2006).

Customary sets of rights and obligations in land tenure that have been created and maintained to facilitate property, land, security, and territorial needs and aspirations will predate and be significantly stronger than laws connected to a state (or treaty) perceived of as having separate interests. This is particularly the case as mechanisms for disseminating and enforcing such laws (especially with agrarian, semi-literate populations) are also weak or nonexistent. Previous analysis of this disconnect has examined its pervasiveness, history, and many problems ranging from agricultural development and investment, to nation building and A/R projects (e.g., Cleaver 2003; Delville 2003; Unruh 2006; Guadagni 2002; McAuslan 2003; de Moor and Rothermund, 1994; Renteln and Dundes, 1994; Bruce and Migot-Adholla, 1994). 
Thus the extent and nature of the tenurial disconnect is well known, but unfortunately not integrated into the carbon sequestration literature.

A manifestation of this disconnect in an $\mathrm{A} / \mathrm{R}$ project context is the assumption that the benefits accrued through forest projects on community land will outweigh the local economic, social, political, and security benefits of the same land under its current use, and that as a result community participation will be forthcoming (e.g., May, et al., 2003; Silver, et al., 2000; Brown, et al., 2001). However social relations regarding current benefits are already in existence with regard to lands and are binding on local communities and individuals within communities, hence the current use. Existing customary or indigenous tenure systems in rural areas comprise ongoing arrangements regarding land which result in tangible benefits, and cannot be easily forced or coaxed out of existence with laws and projects that offer benefits of unknown immediate value, and are not compared to current benefits they will by necessity reduce or extinguish.

\subsection{Tenurial Pluralism}

\subsubsection{Carbon storage, a uniform legal code for land, and good governance}

The need for a uniform set of statutory laws regarding land tenure is commonly thought to be a prerequisite regarding the prospects for carbon forests (e.g. Antle and Diagana, 2003; Smith, 2002; Smith and Sherr, 2002; Makundi, 1998). In Africa the locations where formal title and land markets prevail, are those of most interest to the state and the commercial sector: densely populated areas, locations of intensive agriculture, fertile lands, areas containing high value resources, and lands in proximity to infrastructure. But these are not areas where $\mathrm{A} / \mathrm{R}$ projects will likely be located - unless they will produce a higher income than current or prospective uses in such valuable areas. Instead projects will be put in areas that are marginal, less valuable, degraded, apparently abandoned, inhabited by the poor, less lucrative for intensive agriculture, with political problems, or are otherwise difficult or neglected (Unruh, 1995). Such areas have much less state influence — even though the state can officially 'own' this land. In these areas there is often considerable variation in perceptions about what rights the individual, household, communities, and the state have, resulting in a situation of pronounced temporal and spatial 'legal pluralism' (e.g., Benda-Beckmann, 1995; Merry, 1988; Moore, 1973; Lund, 1998). Such pluralism is different than the customary - statutory divide, in that the interaction over time between many forms of customary tenure (themselves often incompatible, e.g., migration, ethnic differences) as well as changing statutory law (with previous laws e.g., colonial, often not legally superseded by new laws) is the production a very wide variety of understandings about what law applies to whom, when, and how (e.g. Peters, 1994; Shipton 1994). 
The diversity of customary land tenure perceptions and systems in any one African country has frequently frustrated African states' attempts to derive and implement a land law that applies to everyone (Guadgni, 2002; Maganga, 2003; Roberts, 1994; Elias, 1994; McAuslan, 2003; Unsworth, 1994). This same diversity also means that formal law will, despite the recommendations of those desiring a straightforward application of $\mathrm{A} / \mathrm{R}$ projects, not be able to embrace, and thus make legal, even a subset of this variation in ways that are meaningful to the different customary structures, and still be operable as a formal, widely applied, and uniform system (Unruh, 2002, 2006). Globally, the most common examples of legal pluralism regarding land occur in Africa, where due to the existence of both the wide variety of customary tenure, as well as formal tenure systems, accepting legal pluralism in land is an approach to practical governance (Mbembe, 1999; Bruce, 2000; Unruh, 2004). However the 'improved governance' recommended in the carbon sequestration literature as a route to effective implementation of $\mathrm{A} / \mathrm{R}$ efforts in Africa assumes that the result will be a single land law for an entire national population (e.g., Smith, 2002; Niles, et al., 2002; Brown, et al., 2001; Saunders, et al., 2002). Laudable as this may be in theory (e.g. de Soto, 2000), and workable as it is in the developed West, in Africa the reality is that the engagement of legal pluralism in land tenure (and other issues) as good governance recognizes that, 1) significantly different tenurial 'legalities' are a reality and that these are not easily reconciled;2) attempts at forcing one set of tenure rules (e.g. formalized, or one group's customary laws, or a harmonization of different groups' laws) onto such a pluralistic situation has a record of failure and can provoke more problems than it seeks to resolve; and, 3) a degree of benign neglect can be an important aspect of this form of practical governance. Such recognition is important given that a number of potentially serious tenure problems can exist in a latent (but peaceful) state, managed by a purposeful neglect or lack of enforcement of formal law by government. But as the state seeks locations where carbon forests can be located, due to pressure by, or commitment to the international community, the effort will intersect with the three issues noted above. A focus on, and intrusion into latently problematic land tenure situations can drive to the fore a large number of serious rights, access, and use issues (in addition to the viability of $\mathrm{A} / \mathrm{R}$ projects), that individual states, NGOs, and private, commercial, and international development interests will not be in a position to adequately handle. For example, the codification of customary law can in some cases capture and emphasize ethnic differences, as Maganga and Juma (1999) have shown for Tanzania (also Maganga, 2003 more generally). In Sierra Leone and Liberia, efforts at formal, legal demarcation of rural lands by the state so as to move toward Western notions of rural property rights, have met with a great deal of resistance, and at times violence (Unruh, 2005 , in press). 
While the $\mathrm{A} / \mathrm{R}$ carbon sequestration literature can recommend that governments guarantee rights to smallholders because it so clearly works in Western contexts, the codification of property as a way to protect the poor (Saunders, et al., 2002) can have the reverse effect. This is because in Africa the poor often need to be protected from governments, and yet governments will be responsible for law-making, guaranteeing rights, and titling programs (Saunders, et al., 2002). For many rural small-scale property rights holders in Africa, remaining outside of such a codified system or any government backed land system is a priority. Such anonymity offers a degree of protection from the predations of government or elements within government (Unruh, 2002). The utility of ambiguity as a form of protection from government is not easily undone in the minds of smallholders, and is particularly problematic given that governments are usually involved in A/R projects (Desanker, 2006; Meena, 2006).

\subsubsection{Migration and pluralism}

In a legal pluralism context, migration in Africa deserves particular mention as an increasingly continent-wide trend; with the scale of migrations and diversity of migrants and destination locations growing markedly over the past decades (e.g., McGregor, 1994; Myers, 1997; Ghimire, 1994). Migration and environmental change are acutely pertinent to sub-Saharan Africa where some of the highest rates of deforestation in the world exist alongside of some of the largest, most pervasive and problematic migrations (Unruh, et al., 2005; FAO, 2007). Not only are migrants emerging from a wider variety of states and regions within states, but from a wider variety of livelihood systems, religions, ethnic groups, and socioeconomic strata (Schmeidl, 1998). As well, the growing array of specific reasons for dislocation, and the variety of experiences during migration, add to the diversity of migrant characteristics, and importantly, to the diversity of their approaches to rights of land resource access in temporary and permanent destination locations (Myers, 1997; IUCN, 2000).

Diversity in tenurial constructs in a migration context comes about both as migrants carry with them notions about property rights arrangements that are familiar, and seek or are compelled to pursue new constructs in new locations. Thus migration brings distinct tenurial ideas and constructs into contact with those of established in-place communities and the state (often overwhelming these), to result in a significant increase in plural approaches to land tenure (von Benda-Beckmann, 1995; Lund, 1998; Prill-Brett, 1994). Such interaction often embodies the tension between migrants and autochthonous inhabitants of an area (e.g. Geschiere 2005). In Zambia for example, where deforestation rates are among the highest on the continent (FAO, 
2007) such a situation has resulted in an interaction of tenure approaches between migrants and non-migrants that has produced a 'clearing to claim' process with severe deforestation repercussions (Unruh, et al., 2005). Such a process comes about due to pluralism, where no single authority (including the state's) is seen as legitimate and able to implement rules regarding evidence of claim (also Southgate, 1990).

A primary link with $\mathrm{A} / \mathrm{R}$ projects is that migration destinations are often at the frontier of development in marginal, degraded, or apparently abandoned lands, where the state has neglected development or land tenure, or where political instability has likewise caused tenurial confusion and insecurity (e.g., Amacher, et al., 1998; Myers, 1997). Such situations are seen as attractive opportunities for migrants in that they represent the possibility for pursuing various forms of claim for themselves, however temporary or unofficial (Amacher, et al., 1998). As noted however, such locations can also seen as available for $\mathrm{A} / \mathrm{R}$ schemes.

\subsubsection{Large permanent areas versus spatial and temporal plurality}

In a temporal context a great deal regarding African customary land tenure is purposefully fluid, reflecting change in a variety of social, political, and economic variables over time (Antle and Diagana, 2003). While such fluidity is an effective approach to livelihoods in unpredictable biophysical and socio-political environments, it is the opposite of that needed for $\mathrm{A} / \mathrm{R}$ carbon storage projects, which require secure, predictable tenure arrangements over the long-term. Such that if carbon A/R contracts are established, but then a change in forms of tenure are needed by smallholders, then "buyers of carbon contracts will have little recourse if farmers are found not to be complying with the terms of the contract" (Antle and Diagana, 2003, p. 1182).

In a spatial context the establishment of secure $\mathrm{A} / \mathrm{R}$ carbon storage at the lowest price will tend toward the acquisition of large, contiguous areas that are to be put under fairly simple land management and very clear tenure arrangements, which can more easily guarantee carbon storage as a verifiable commodity for a number of years (Bass, et al., 2000; Saunders, et al., 2002). May, et al., (2003, p. 13) note,

"[f]orest carbon projects, like production of some agricultural commodities, depend on a reasonably large minimum area to guarantee profitability/ viability. Due to the considerable transactions costs, particularly those incurred in negotiation of contracts, carbon monitoring, carbon credit, commercialization, and technical assistance for planting and growing trees, large areas are typically necessary to amortize these costs." Realizing such large areas under carbon forests in a smallholder tenure environment would be extremely difficult due to the spatial and temporal variability in tenure holdings. On the other hand government consolidation of customary and other 
holding types in order to achieve such a reasonably large minimum area would present still another problem. From a social and tenurial perspective this would contribute to a process of rural land concentration. "In this sense, the carbon market would repeat the same process that occurred with other agricultural and industrial forest commodities in developing countries, such as coffee, sugarcane, and eucalyptus" (May, et al., 2003, p. 13). Smith (2002, p. 328) notes that "[t]he most significant social risk is that industrial plantations supported by CDM funds could exacerbate existing disparities in land distribution and deprive communities of customary land rights and livelihood needs." Already "[t]enure conflicts are a common feature of plantations in many parts of the world where land has been acquired through intimidation or insufficiently compensated" (Smith, 2002, p. 328; also Morrison and Bass, 1992; Smith and Scherr, 2002; Saunders, et al., 2002; FERN, 2000; Peluso, 1992).

The rural poor in Africa most often pursue a livelihood system (and supporting tenure system) that capitalizes on spatial and temporal flexibility in the short-term (especially when compared to the requirements for carbon storage). This means frequent change in land resource use and access, and dependence on multiple areas and products (Basss, et al., 2000). If large areas become managed for long-term carbon storage, local people will lose access to land, food, and fiber (Bass, et al., 2000). In this regard the clarity and predictability aspects needed for carbon $A / R$ and the supporting forms of land tenure, are the opposite of what would most benefit the rural poor in Africa. This has implications for the assumed connection with sustainable development.

\subsection{Tree tenure}

The pervasive and powerful notion in Africa that tree planting signifies land claim, has thwarted many A/R and other development projects. (Brokensha and Glazier, 1973; Fortmann, 1987; MacDicken, 1990; Riddell, 1987). The literature regarding the strong and pervasive tenure role of trees is significantly large (Raintree, 1987; Meinzen-Dick, et al., 2002; Otsuka, et al., 2001; Rocheleau and Edmunds, 1997; and Fortmann and Riddell, 1985 is an annotated bibliography on the topic with 414 entries). However very little on tree tenure is noted in the literature on carbon sequestration, revealing the existence of a gap between these two literatures, and hence in our understanding of the real socio-political constraints of carbon sequestration in Africa. Purposefully planted trees are notable for their pervasive role as forms of claim within customary systems. That tree planting serves as land claim is underscored by strong customary restrictions on tree planting for certain groups (such as women, tenants, migrants and other 'outsiders'). In African smallholder tenure systems, trees are planted to delimit clear boundaries and to establish or increase 
security of tenure; with Sjaastad and Bromley (1997) articulating the connection between customary tenure security and forms of investment, including tree planting. Thus A/R projects which provide trees to customary occupants of land for planting often encounter significant difficulty due to the perceived changes in land rights that result--such as attempts at permanent, individual claim of rented, borrowed, squatted, or common land, or individualization of lineage held land (Unruh, 1995). Such acts of claim can aggravate pre-existing formal and informal claim(s) and result in problems greater than just destruction of planted trees and a failed forestry project (e.g. Brokensha and Glazier, 1973; Chavangi, 1987; Fortmann, 1987). And plantation forestry is generally viewed locally as usurping rights, uses, and claims (e.g. MacDicken, 1990; Meek, 1968; Riddell, 1987). In Africa purposefully planted trees "play an integral role in defining local cultures and institutions" (Saunders, et al., 2002, p. 1765), and are indicators of broad societal rights (Saunders, et al., 2002). Thus from a customary perspective tree planting can be used by 'outsiders' to claim land, effectively transferring that land to the outsider's control. This is an important consideration when a Forestry Department, NGO, private enterprise, etc., seeks to access land to plant trees, even if trees are given to local communities (Riddell, 1987; Unruh, 1995).

In whatever way the spatial placement of trees is attempted, those who hold, or attempt to hold a variety of rights (weakly, strongly, partial, individual, group, etc.) will seek to ensure security of access at least, and expansion of access at best. Thus because such tree planting, particularly large-scale tree planting, changes social relations with regard to land, an $\mathrm{A} / \mathrm{R}$ project will serve to remove the rights and benefits of some, make more ambiguous the rights and benefits of others, and allow the opportunity for the expansion of rights and benefits of still others. This will occur in an ongoing and continually contested way, with planted trees the medium of this contestation (Unruh, 1995, 2006).

An additional problem is that useful trees and forest resources in Africa are commonly viewed as complexes of rights in which different parts of useful trees at different periods of time, differ in terms of who owns, loans, borrows, inherits, uses, or disposes of them (Saunders, et al., 2002; Fortmann, 1987). This will significantly complicate a carbon forest project due to the number of people with different rights, interests, and obligations in the project's trees. And because sequestration projects will add to the number of rights associated with trees and forests (including carbon rights) (Saunders, et al., 2002), they will also add to the various ways rights to trees and forests can be claimed over time. This, again, is the opposite from the simple, clear tenure rights regimes recommended by analysis of $\mathrm{A} / \mathrm{R}$ type carbon sequestration (Antle and Diagana, 2003; Smith, 2002; Smith and Sherr, 2002; FERN, 
2000; Godinho, et al., 2003; Makundi, 1998).

\subsection{Expansion of areas under trees on smallholder African landscapes}

In Africa there is an important distinction between large-scale expansion of treed areas occurring on its own due to a wide variety of local tenurial and other reasons (e.g. Coghlan, 2006; Unruh, 1994), and expansion due to projects or outside priorities and approaches. The difference is fundamental. Implementation and maintenance of $\mathrm{A} / \mathrm{R}$ in a project approach involves fundamentally different tenurial and sociopolitical realities (even if the community 'participates'), than does a more informal, and much less measurable and predictable 'loading' of trees onto agricultural and other extensively used landscapes. The latter comes about due to the interaction between localized ecological, historical, production system, political, and socioeconomic reasons which function within customary tenure constructs that often involve transitory or seasonal rights, and different rights for users of the land, trees, or tree products. The former requires comparatively more intensive land management approaches, and simple tenurial arrangements that are more certain and predictable, and purposefully reduces ambiguity with regard to land rights as a priority. The latter uses and seeks to retain tenurial ambiguity and extensive land uses to facilitate the fluidity and options needed to support local livelihoods (Unruh, 1994).

Numerous examples from the tropics highlight this distinction. These include a type of acacia (Faidherbia albida) along the southern edge of the Sahel (Coghlan 2006); Acacia (Acacia tortilis (Forsk.) Hayne) in several taxonomic forms, which range widely in the arid and semi-arid zones of Africa (Le Houerou and Corra, 1980); and the spread of Acacia albida over tens of thousands of square kilometers of African landscape where it would not naturally occur (Poschen, 1986). In these cases domesticated stock act as long distance dispersers of the pods of these trees as they roam clan held land and are herded to various grazing and watering locations accessed via clan tenure rules. Different examples include the oil palm of west Africa (Elaeis guineensis Jacq.) (Harlan, 1975); the gum tree (Acacia senegal (L.) Willd.) (Abdul, 1987); and neem (Azadirachta indica) (Taylor and Soumare, 1983).

Many of the examples where large-scale increases in treed areas are observed, are these more naturally occurring cases, subject to ongoing change and fluidity in ownership and use rights, tree density, and species. And while carbon is sequestered in these scenarios, it occurs in ways not amenable to the more easily measured $\mathrm{A} / \mathrm{R}$ project approach. In these more naturally occurring cases, predictability in the spatial and temporal aspects of woody biomass would be quite difficult in a carbon storage context. 


\subsection{The 'abandoned land' problem}

The idea of the availability of seemingly 'abandoned lands' for A/R projects in Africa and elsewhere in the developing world, while popular (e.g. Lugo and Brown, 1992; Makundi, 1998; Brown, et al., 2001; Smith, 2002; Niles, et al., 2002) is in reality a primary misconception in need of considerable socio-political research. The apparent enormity of this category of land is indeed tempting. Silver, et al., (2000, p. 394) note that "(a)pproximately half of the tropical biome is in some stage of recovery from past human disturbance, most of which is in secondary forests growing on abandoned agricultural lands and pastures." The biophysical potential for carbon sequestration on such lands is equally tempting. Achard, et al., (2002) find for Africa that the maximum estimated accumulation of carbon on abandoned lands is approximately $179 \mathrm{tC} \mathrm{ha}^{-1}$, the highest measure for any region outside of the Brazil.

There are several misunderstandings regarding the availability of the 'abandoned land' category. One of these is that while 'natural' (meaning non-intentional) carbon sequestration on abandoned lands is thought to presently account for significant sequestration (e.g. Malhi, et al., 2002), as noted previously this does not mean that the tenurial arrangements that allow for this will also allow for the intentional location of carbon forests on such land. In fact the opposite is more likely the case (Unruh, 2002). In an African land tenure context there is a profound distinction between 'unoccupied' and 'abandoned' land, a distinction lacking in the carbon sequestration literature on $\mathrm{A} / \mathrm{R}$. The reality in Africa is that land is rarely if ever actually 'abandoned' and open to new acquisition, occupation or use, even if degraded and not presently occupied. Tribes, chiefdoms, lineages and clans claim vast areas within which degraded and unoccupied lands exist; and on which attempts at planting trees by 'outsiders' or at the behest of outsiders would be hotly contested (e.g., Unruh, 2005, in press). And "in many cases, 'degraded' areas targeted for CDM plantations may be common property resources used by local people, particularly the poorest households, for a variety of uses such as fuel supplies and grazing" (Smith, 2002, p. 328; also Jodha, 1986). Pastoralist land use can be a primary example of this misunderstanding. Leaving little in the way of visible evidence of use, and disfavored in national laws, pastoralists' transient or seasonal rights are often not taken into account in assessments of land use, claim, or occupation. Thus statements such as, "large extensions of land are under control of governments in some countries in this [abandoned] category" (Smith, 2002, p. 326) are quite problematic. In reality the notion of such 'government control' is often mere assertion, or contested.

As well, contrary to land currently under obvious use, where the owner or defacto user is evident, the situation with degraded and apparently abandoned lands is 
tenurially more complex, not less. Previously forested, presently degraded and seemingly unused lands have undergone or are presently undergoing, a nonsustainable land use which effectively eliminates forest regrowth and obvious occupants, constituting the problem of who to go to for acquiring access to the land (Unruh, 1995). And while these areas may have biophysical potential for $A / R$, it is almost certain that such areas are already extremely problematic in terms of land policy, land use, population density, tenure, poverty, etc., which is why they are degraded (Saunders, et al., 2002; Unruh, 1995). The incomplete and confused nature of land registration and transfer procedures, and land registries and records in African countries, and the fact that many actual claimants and users of land are not included in local or national registries, means that they are not contacted or taken into account when a site for A/R is being considered. Bruce and Migot-Adholla's (1994) edited volume contains numerous African examples of such exclusion. Locally however, it may be generally recognized that such inhabitants are current owners or users of the land. Overall the total area that would be most difficult for establishment of carbon forests in Africa is the same as that indicated by some of the carbon storage $A / R$ literature as being most available_-abandoned lands.

If it is determined locally that a tract of land is in fact not presently owned or inhabited, the establishment of an A/R project will bring to the surface historical claims (which will likely not be verifiable) brought on by a perceived increase in land value due to the establishment of, or even the possibility of a project in the area. Such situations can cause a flurry of formal and informal tenure claim activity as locals and outsiders attempt to 'cash in' on perceived claims and increases in land values due to project site consideration (Unruh, 1995). In such situations it can be extremely difficult to determine who has actual rights in order to engage in community participation exercises. And dispute resolution and compensation in such a context can take long periods of time and become very involved. The resulting problems can include $\mathrm{A} / \mathrm{R}$ project delays or failure, larger than expected expenditures, and the derivation of a host of informal 'special arrangements' which serve to highlight the transient nature of the project (Unruh, 1995).

More broadly, definitions or classifications of abandoned, degraded, uninhabited or unclaimed land can vary widely in local, national, academic, and international (UN, World Bank, etc.) contexts. African governments located in capital cities far from outlying regions are frequently not knowledgeable about the workings of many rural areas, particularly areas involved in extensive production systems. 'Official' statements and claims about land tenure, land classification, land use practice, and population are frequently not made on the basis of the comparatively rigorously gathered and processed information known to industrialized countries (Achard, et al., 
2002). In many areas, personal, tribal, ethnic, and local, regional, national, and international political considerations can play as important or more important a role in land classification, than the accurate examination of information and well conducted land use and tenure surveys. Thus regardless of the official classification of land, if there are communal or customary rights to land, or if there are ambiguous or unenforceable rights to exclude others from land, then an $\mathrm{A} / \mathrm{R}$ project will be in difficulty (Fortmann, 1987).

\section{Conclusions}

Few A/R schemes in the developed world are subject to the kinds of tenure complexities and pressures caused by land hungry peasants, and the shifts in livelihood, economy, and politics which exist in Africa (Bruce and Fortmann, 1989). This presents a human environment whereby planting and maintaining large areas (or many small areas) of long-rotation new forests will be very difficult. As a result, in most of Africa it can be extremely complicated to realistically estimate normal forestry parameters and thus a $\mathrm{A} / \mathrm{R}$ stands' ability to sequester carbon.

Malhi, et al., (2002) point out that the proportional contribution that $\mathrm{A} / \mathrm{R}$ could make to the global total carbon offset would be sufficient enough to move from the 'business as usual' scenario, to a 'low-emissions' scenario. However "[a]s the century progresses and the magnitude of the required carbon reductions increases, the relative potential of forest-carbon sinks declines" (Malhi, et al., 2002, p. 1587). "Thus to be relevant, a forest-carbon sequestration programme has to absorb most of its carbon within the next few decades. Tropical ecosystems have the highest productivities, and are therefore likely to be the most effective sinks at this short time-scale" (Malhi, et al., 2002, p. 1587). This presents a significant problem with regard to land tenure and carbon sequestration in Africa. Given the land tenure obstacles to the A/R approach, will it be possible to realize sequestration goals within the time whereby the impact will be meaningful?

Ultimately what the current carbon forest endeavor assumes, is that the entire national population of a country possess the same or similar ideas about land tenure (and the attendant market, economy, politics, and identity variables); or that getting everyone included is a simple legislative, nation building, or governance endeavor. In other words that everyone plays, or can or will play, by the same rules with regard to land tenure. However decades of development effort and billions of dollars in foreign assistance have pursued this general idea of tenurial inclusiveness in Africa. And yet diverse forms of customary tenure is how most Africans continue to get by, and a minority understand how the state tenure system works, how the state works, or hold 
it to be the prevailing idea with regard to property rights. In the $\mathrm{A} / \mathrm{R}$ carbon sequestration literature, as well as the forest planting aspects of the CDM, sustainable development, and governance are currently connected by a set of assumptions that differ markedly from the African tenurial reality. While tree planting efforts are laudable, the prospect for carbon sequestration via $A / R$ projects in Africa, for tenure reasons alone, appear fairly unrealistic.

\section{References}

Achard, F., Eva, H., Stibig, H., Mayaux, P., Gallego, J., Richards, T., Malingreau, J. (2002) Determination of deforestation rates of the world's humid tropical forests. Science 297, 999-1002.

Amacher, G.S., Cruz, W., Gerbner, D., and Hyde, W.F. (1998) Environmental motivations for migration: population pressure, poverty and deforestation in the Philippines. Land Economics 74, 92-101.

Antle, J.M., and Diagana, B. (2003) Creating incentives for the adoption of sustainable agricutlrual practices in developing countries: the role of soil carbon sequestration. American Journal of Agricultural Economics 85, 1178-1184.

Batjes N. H. (2001) Options for increasing carbon sequestration in West African soils: an exploratory study with special focus on Senegal. Land Degradation and Development 12, 131-142.

Bass, S., Budois, O., Costa, P.M., Pinard, M., Tipper, R., and Wilson, C. (2000) Rural Livelihoods and Carbon Management. IIED Natural Resource Issues Paper No. 1. International Institute for Environment and Development, London.

Benda-Beckmann, F. von. (1995) Anthropological approaches to property law and economics. European Journal of Law and Economics 2, 309-336.

Berry, S. (1997) Tomatoes, and hearsay: property and history in Asante in the time of structural adjustment. World Development 25 (8): 1225-1241.

Berry, S. (1990) Land tenure and agricultural performance in Africa: report on a conference. Paper presented at the Conference on Rural Land Tenure, Credit, Agricultural Investment, and Farm Productivity, June 4-8 1990, Nairobi.

Black, R. (2006) Africa focus for climate summit. BBC News, Nov 6. 
Braatz, B.V., Brown, S., Isichei, A.O., Odada, E.O., Scholes, R.J., Sokona, Y., Drichi, P., Gaston, G., Delmas, R., Holmes, R., Amous, S., Muyungi, R.S., de Jode1, A., and

Brokensha, D., and Glazier, J. (1973) Land reform among the Mbeere of Central Kenya. Africa, 182-206.

Brown, S., Swingland, I., Hanbury-Tension, R., Prance, G., Myers, N. (2001) Carbon Sinks for Abating Climate Change: Can They Work? Center for Environment and Society, University of Essex.

Brown, S. (2002) Changes in the use and management of forests for abating carbon emissions: issues and challenges under The Kyoto Protocol. Philosophical Transactions: Mathematical, Physical and Engineering Sciences. 360, 1593-1605.

Bruce, J.W., and Migot-Adholla, S.E. (eds.) (1994) Searching for Land Tenure Security in Africa. Kendall/Hunt Publishing Co., Dubuque USA.

Bruce, J.W. (2000) African tenure models at the turn of the century: individual property models and common property models. Land Reform 1, 17-27.

Bruce, J.W., Noronha, R. (1987) Land Tenure Issues In The Forestry And Agroforestry Project Contexts. In: Raintree, J.B. (ed.) Land, Trees and Tenure. Proceedings of an International Workshop on tenure Issues in Agroforestry, Land Tenure Center, International Council for Research in Agroforestry, Nairobi, May 27-31, 1985

Bruce, J., and Fortmann, L. (1989) Agroforestry: Tenure and Incentives. Land Tenure Center Paper No. 135. The Land Tenure Center, Madison, WI.

Chavangi, N.A. (1987) Agroforestry Potentials and Land Tenure Issues in Western Kenya. In: Raintree, J.B. (ed.) Land, Trees and Tenure. Proceedings of an International Workshop on tenure Issues in Agroforestry, Land Tenure Center, International Council for Research in Agroforestry, Nairobi, May 27-31 (1985

Cleaver, F. (2003) Reinventing institutions: bricolage and the social embeddedness of natural resource management. In Securing land rights in Africa, eds. Benjaminsen, T.A., and Lund, C. London: CASS Publishing.

Coghlan, A. (2006) More crops for africa as trees reclaim desert. New Scientist 2573, 14 October. 
Creedy, J. and Wurzbacjer, A.D. (2001) The economic value of a forested catchment with timber, water and carbon sequestration benefits. Ecological Economics 38, 71-85.

Delville, P. L. (2003) When farmers use 'pieces of paper' to record their land transactions in Francophone rural Africa: insights into the dynamics of institutional innovation. In Securing land rights in Africa, Benjaminsen, T.A., and Lund, C., London: CASS Publishing.

Demsetz, H. (1967) Towards a theory of property rights. American Economic Review, Papers and Proceedings 57 (2): 347-359

De Moor, J., and Rothermund, D. (eds.) (1994) Our Laws, Their Lands: Land Laws and Land Use in Modern Colonial Societies. Lit Verlag, Uppsala.

Desanker, P.V. (2006) The Kyoto Protocol and the CDM in Africa: a good idea but... Impact - Newsletter of Climate Network Africa, November, 17-20.

Elias, T.O. (1994) The Problem of Reducing Customary Laws to Writing. In: Renteln, A.D., and Dundes, A. (eds.) Folk Law: Essays in The Theory And Practice of Lex Non Scripta: Volume I, University of Wisconsin Press, Madison, WI, 319-330.

Evers, S., Spierenburg, M., and Wels, H. (2005) Competing Jurisdictions: Settling Land Claims in Africa. Brill, Leiden.

Food and Agriculture Organization of the United Nations (FAO) (2007). Table 2, forest area and area change. State of the World's Forests, FAO, Rome.

FERN (2000) Sinking the Kyoto Protocol: the Links Between Forests, Plantations and Carbon Sinks. FERN Briefing Note in Cooperation with Both Ends. FERN, October, Moreton-in-Marsh, UK.

Fortmann, L. (1987) Tree Tenure: an Analytical Framework For Agroforestry Projects. In: Raintree, J.B. (ed.) Land Trees and Tenure, ICRAF and the Land Tenure Center, Nairobi and Madison.

Fortmann, L., and Riddell, J., (eds.) (1985) Trees and Tenure: An Annotated Bibliography for Agroforesters and Others. Land Tenure Center, Madison, and the International Council for research in Agroforestry, Nairobi. 
Geschiere, P. (2005) Autochthony and citizenship: new modes in the struggle over belonging and exclusion in Africa. Forum for Development Studies 32, 371-384

Ghimire, K. (1994) Refugees and deforestation. International Migration 32, 561-569.

Griffiths, J. (1986) What is legal pluralism? Journal of Legal Pluralism 24, 1-52.

Godinho, L., Nacuray, E., Cardinoza, M.M., Lasco, R.D. (2003) Climate Change Mitigation Through Carbon: the Forest Ecosystems of Timor Leste. Proceedings from the 1st National Workshop on Climate Change, Dili (19 November.

Guadagni, M. (2002) Trends in Customary Land Property. In: Jordan, M.E.S., and Gambaro, A. (eds.) Land Law in Comparative Perspective. Kluwer Law International, New York.

Harlan, J.R. (1975) Crops and Man. American Society of Agronomy, Madison, WI, 64-96.

Houghton, R., and Hackler, J. (2001) Carbon Flux to the Atmosphere From Land-Use Changes: 1850-1990. ORNL/CDIAC-131 NDP-050/RI, Carbon Dioxide Information Analysis Center, Oak Ridge National Laboratory, Oak Ridge, TN.

IUCN (2000) IUCN-CEESP Environment and Security Task Force Briefing. IUCN. Presented at the World conservation Conference, Amman.

Jodha, N.D. (1986) Common property resources and rural poor in dry regions of India. Economic and Political Weekly, 21-27.

Kauppi, P., and Sedjo, R. (2001) Technical and Economic Potential of Options to Enhance, Maintain and Manage Biological Carbon Reservoirs and Geo-Engineering. Chapter 4 in IPCC Third Assessment Report, Cambridge University Press, Cambridge, London.

Lal, R. (2002) Carbon sequestration in dryland ecosystems of West Asia and North Africa. Land Degradation and Development 13, 45-59.

Le Houerou, H.N., Corra, M. (1980) Some Browse Plants of Ethiopia. In: Le Houerou, H.N. (ed.) Browse in Africa, ILCA, Addis Ababa, 109114. 
Lugo, A.E., and Brown, S. (1992) Tropical forests as sinks of atmospheric carbon. Forest Ecology and Management 54, 239-255.

Lund, C. (1998) Struggles for land and political power: on the politicization of land tenure and disputes in Niger. Journal of Legal Pluralism 40, 1-22.

MacDicken, K.G. (1990) Agroforestry Management in the Humid Tropics. In: MacDicken, K.G., and Vergara, N.T. (eds.) Agroforestry: Classification and Management. John Wiley and Sons, New York.

Makundi, W. (1998) Mitigation Options in Forestry, Land Use Change and Biomass Burning in Africa. Berkeley National Laboratory, LBNL-42767, University of California, Berkeley.

Malhi, Y., Meir, P., Brown, S. (2002) Forests, carbon, and global carbon.

Philosophical Transactions of the Royal Society, London. A. 360, 1567-1591.

Magnaga, F., and Juma, I. (1999) From customary to statutory systems: changes in land and water management in irrigated areas of Tanzania: A study of local resource management systems in Usangu Plains. A report submitted to ENRECA, Dar es Salaam, Sept.

Maganga, F. (2003) The Interplay Between Formal and Informal Systems of Managing Resource Conflicts: Some Evidence From South-Western Tanzania. In: Benjaminsen, T.A., and Lund, C. Securing Land Rights in Africa. Frank Cass Publishing, London.

May, P.H., Boyd, E., Chang, M., and Viega, F.C. (2003) Local Sustainable Development Effects of Forest Carbon Projects in Brazil And Bolivia: a View From the Field. Paper presented at the International Conference on Rural Livelihoods, Forests and Biodiversity. 19-23 May 2003, Bonn Germany.

Mbembe, A. (1999) Migration of peoples, disintegration of states: Africa's frontiers in flux. Le Monde Diplomatique, November.

McAuslan, P. (2003) Bringing The Law Back In: Essays in Land Law and Development. Ashgtate Publishing Limited, Burlington, VT.

McGregor, J. (1994) Climate change and involuntary migration: implications for food security. Food Policy 19, 120-132. 
Meek, C.K. (1968) Land Law and Custom in the Colonies. Second Edition, Frank Class, London.

Meena, H. E. (2006) Why the clean development mechanism has not been successful in africa - a way forward. Impact: Newsletter of Climate Network Africa, November, 21-23.

Meinzen-Dick, R., Mcculloch, A., Place, F., and Swallow, B. (2002) Innovation in Natural Resource Management: the Role of Property Rights and Collective Action in Developing Countries. Johns Hopkins University Press, London.

Merry, S.E. (1988) Legal pluralism. Law and Society Review 22, 869-896.

Moore, S. (1973) Law and social change: the semi-autonomous social field as an appropriate field of study. Law and Society Review 7, 719.

Morrison, E., and Bass, S.J.M. (1992) What about the people? In: Sargent, C., and Bass, S. (eds.) Plantation Politics: Forest Plantations in Development. Earthscan Publications Ltd., London.

Moyo, S., and Yeros, P. (2005) Reclaiming the Land: The Resurgence of Rural Movements in Africa, Asia, and Latin America. Zed Books, London.

Myers, N. (1997) Environmental refugees. Population and Environment 19, 167-182.

Niles, J.O., Brown, S., Pretty, J., Ball, A.S., and Fay, J. (2002) Potential carbon mitigation and income in developing countries from changes in use and management of agricultural and forest lands. Philosophical Transactions of The Royal Society of London 360, 1621-1639.

Okoth-Ogendo, H. W. O. (2000) Legislative approaches to customary tenure and tenure reform in East Africa. In Evolving land rights, policy and tenure in Africa, eds. Toulmin, T., and Quan, J. 123-134. London: Natural Resources Institute.

Otsuka, K., Suyanto, S., Sonobe, T., Tomich, T. P. (2001) Evolution of land tenure institutions and development of agroforestry: evidence from customary land areas of Sumatra. Agricultural Economics 25, 85-101. 
Peluso, N.L. (1992) Rich Forest Poor People: Resource Control and Resistence in Java. University of California Press, Berkeley.

Perez, C., Roncoli, C., Neely, C., and Steiner, J. (2007) Can carbon sequestration markets benefit low-income producers in semi-arid Africa? potentials and challenges. Agricultural Systems 94, 109-126.

Peters, P.E. (1994) Dividing the commons: Politics, policy, and culture in Botswana. University of Virginia Press, Charlottesville.

Platteau, J.P. (1996) The Evolutionary Theory of land rights as applied to sub-Saharan Africa: a critical assessment. Development and Change 27, 29-86.

Poschen, P. (1986) An evaluation of the Acacia albida-based agroforestry practices in the Hararghe Highlands of Eastern Ethiopia. Agroforestry Systems 4, 129-143.

Prill-Brett, J. (1994) Indigenous land rights and legal pluralism among Philippine highlanders. Law and Society Review 28, 687-697.

Quan, J. (2000) Land tenure, economic growth and poverty in subSaharan Africa. In Evolving land rights, policy and tenure in Africa, eds. Toulmin, T., and Quan, J. 31-50. London: Natural Resources Institute.

Raintree, J.B., (ed.) (1987) Land, Trees and Tenure. ICRAF and the Land Tenure Center, Nairobi and Madison, 217-224.

Renteln, A.D., and Dundes, A. (eds.) (1994) Folk Law: Essays in the Theory and Practice of Lex Non Scripta. Vols I, II. University of Wisconsin Press, Madison.

Richards, K., and Andersson, K. (2001) The leaky sink: persistent obstacles to a forest carbon sequestration program based on individual projects. Climate Policy 1 , $41-54$.

Riddell, J.C. (1987) Land Tenure and Agroforestry: a Regional Overview. In: Schebesta, P. (ed.) Among the Forest Dwarves of Malaya. Oxford University Press, London.

Ringius, L. (2002) Soil carbon sequestration and the cdm: opportunities and challenges for Africa. Climatic Change 54, 471-495. 
Roberts, S. (1994) The Recording of Customary Law: Some Problems of Method. In: Renteln, A.D., and Dundes, A. (eds.) Folk Law: Essays in the Theory And Practice of Lex Non Scripta: Volume I. University of Wisconsin Press, Madison, 331-338.

Rocheleau, D., and Edmunds, D. (1997) Women, men and trees: gender, power and property in forest and agrarian landscapes. World Development 25, 1351-1371.

Saunders, L.S., Hanbury-Tenison, R., and Swingland, I.R. (2002) Social capital from carbon property: creating equity for indigenous people. Philosophical Transactions of the Royal Society London 360, 1763-1775.

Sayer, J., Chokkalingam, U., and Poulsen, J. (2001) The Restoration of Forest Biodiversity and Ecological Values. International Seminar on Restoration Research on Degraded Forest Ecosystems, College of Agriculture and Life Sciences, Seoul, Korea, 13-15 April.

Schmeidl, S. (1998) Comparative Trends in Forced Displacement. In: Hampton, J. (ed.) Internally Displaced People: A Global Survey. Earthscan Publications, London.

Shipton, P. (1994) Land and culture in tropical Africa: Soils, symbols, and the metaphysics of the mundane. Annual Review of Anthropology 23: 347377.

Silver, W., Ostertag, R., and Lugo, A. (2000) The potential for carbon sequestration through reforestation of abandoned tropical agricultural and pasture lands.

Restoration Ecology 8, 394-407.

Sjaastad, E., Bromley, D.W. (1997) Indigenous land rights in sub-Saharan Africa: appropriation security, and investment demand. World Development 25, 549-562.

Smith, J., and Sherr, S.J. (2002) Capturing the value of forest carbon for local livelihoods. World Development 31, 2143-2160.

Smith, J. (2002) Afforestation and reforestation in the clean development mechanism of the Kyoto protocol: implications for forests and forest people. International Journal of Global Environmental Issues 2, 322-343.

de Soto, H. (2000) The Mystery of Capital: Why Capitalism Triumphs in the West and Fails Everywhere Else Basic Books, New York. 
Southgate, D. (1990) The causes of land degradation along "spontaneously" expanding agricultural frontiers in the Third World. Land Economics 66, 93-101.

Taylor, G.F., and Soumare, M. (1983) Strategies of Forestry Development in the Semi-Arid Tropics: Lessons from the Sahel. In: Wiersum, K.F. (ed.) Strategies and Designs for Afforestation, Reforestation, and Tree Planting. Pudoc, Wageningen.

The Royal Society (2001) The Role Of Land Carbon Sinks In Mitigating Global Climate Change. Policy Document 10/01 pp. 1-27

Toulmin, C., Huq, S., and Rockstrom, J. (2005) Africa and Climate Change. International Institute for Environment and Development, Sustainable Development Opinion, London.

Trexler, M., and Haugen, C. (1995) Keeping it Green: Tropical Forestry Opportunities for Mitigating Climate Change. Washington DC, World Resources Institute and Environmental Protection Agency.

Unruh, J.D. (1994) The role of land use pattern and process in the diffusion of valuable tree species. Journal of Biogeography 21, 283-295.

Unruh J.D. (1995) Agroforestry, reforestry, and the carbon problem: the role of land and tree tenure. Interdisciplinary Science Reviews 20, 215-227.

Unruh, J.D. (2002) Poverty and property rights in the developing world: not as simple as we would like. Land Use Policy 19, 275-276.

Unruh, J.D. (2004) Migration Induced Legal Pluralism in Land Tenure: Implications for Environmental Change. In: Unruh, J.D., Krol, M.S., Kliot, N. (eds.) Environmental Change and its Implications for Population Migration, Kluwer, Dordrecht, The Netherlands.

Unruh, J.D., Cliggett, L., Hay, R. (2005) Migrant land rights reception and 'clearing to claim' in sub-Saharan africa: a deforestation example from southern Zambia. Natural Resources Forum 29, 190-198.

Unruh, J.D. (2005) Land Tenure and its Relationship to Food Security and Investment in Postwar Sierra Leone. Technical paper prepared for the Food and Agriculture Organization of the United Nations. FAO, Rome. 
Unruh, J.D. (2006) Land tenure and the evidence landscape in the developing world. Annals of the Association of American Geographers 96, 754-772.

Unruh, J.D. (in press) Land rights in postwar Liberia: the volatile part of the peace process. Land Use Policy.

Unsworth, E.G. (1994) The Conflict of Laws in Africa. In: Renteln, A.D., Dundes, A. (eds.) Folk Law: Essays in the Theory and Practice of Lex Non Scripta: Volume I. University of Wisconsin Press, Madison, 795-804.

Van der Merwe, C. (2008) Africa lags far behind in CDM projects. Engineering News, 25 June, 